\title{
Review of ovarian carcinoma with peritoneal metastasis: Rethinking of management
}

\author{
Peritoneal metastazlı over karsinomunun derlemesi: Yaklaşımın yeniden düşünülmesi
}

Emel Canbay $^{1,2}$, Tülay İ́rez ${ }^{3}$, Yutaka Yonemura ${ }^{1,2}$

\section{Abstract}

Epithelial ovarian carcinoma (EOC) is a type of cancer that is usually diagnosed in advanced stages. To date, the standard treatment of EOC is surgery with neoadjuvant or adjuvant platin and taxane-based systemic chemotherapies. Hyperthermic intraoperative intraperitoneal chemotherapy (HIPEC) is considered in cases of recurrence of EOC. HIPEC has been accepted as a gold standard for treating pseudomyxoma peritonei of ovarian and appendiceal origin. More recently, a randomized clinical trial supports that HIPEC is a promising treatment option for peritoneal metastasis (PM) of primary ovarian cancer $(\mathrm{OC})$ in surgical series. HIPEC is also an effective treatment option in primary and recurrent cancer cases with PM of OC. As a result, the standardization and optimization of the HIPEC technique, determination of patient subgroups with PM of the OC responding to treatments, personalized evaluation, and the treatments currently carried out by the multidisciplinary team still need to be re-evaluated. This review aimed to update the standard treatment approach in PM of OC, along with the systemic treatments and HIPEC treatment approaches combined with surgery.

Keywords: Peritoneal metastasis, ovarian cancer, HIPEC, cytoreductive surgery, hyperthermic intraperitoneal intraoperative chemotherapy.
Öz

Epitelyal tipte over karsinomu (EOK), genellikle ileri evrelerde teşhis edilen bir kanser türüdür. Günümüzde, EOC'nin standart tedavisi neoadjuvan veya adjuvan platin ve taksan bazlı sistemik kemoterapi ile kombine edilen cerrahidir. EOC'nin rekürrensinde hipertermik intraoperatif intraperitoneal kemoterapi (HIPEK) düşünülmektedir. HIPEK, over ve apendiks kaynaklı psödomiksoma peritonei tedavisinde altın standart olarak kabul edilmiştir. Son zamanlarda, randomize bir klinik çalışma, HIPEK'in, cerrahi serilerde primer over kanserinin $(\mathrm{OK})$ peritona metastazı $(\mathrm{PM})$ için umut verici bir tedavi seçeneği olduğunu desteklemektedir zamanlarda, randomize bir klinik çalışma, HIPEK'in, cerrahi serilerde primer over kanserinin (OK) peritona metastazı (PM) için umut verici bir tedavi seçeneği olduğunu desteklemektedir. HiPEK'in ayrıca primer ve rekürren OK'nin PM vakalarında da etkili bir tedavi seçeneği olduğu bildirilmektedir. Sonuç olarak, HiPEK tekniğinin standardizasyonu ve optimizasyonu, OK'nin PM olan hastalarda tedavilere yanıt veren alt gruplarının belirlenmesi, hali hazırda kişiselleştirilmiş değerlendirme ile multidisipliner ekip tarafindan yürütülen tedavilerin yeniden değerlendirilmesi gerekmektedir. Bu derlemede OK'nin PM durumunda standart tedavi yaklaşımı ile birlikte uygulamadaki sistemik tedaviler ve cerrahi ile kombine edilmiş HiPEK tedavi yaklaşımlarının güncellenmesi amaçlanmıştır.

Anahtar Kelimeler: Periton metastazı, over kanseri, HIPEK, sitoredüktif cerrahi, hipertermik intraperitonea intraoperatif kemoterapi
1 NPO Center for Peritoneral Surface Malignaancies, Istanbul, Turkey.

${ }^{2}$ Peritoneal Surface Malignancy Center, Dept of Regional Cancer Therapy, Kishiwada Tokushukai Hospital, Kishiwada, Japan.

${ }^{3}$ Yeni Yüzyil University, Faculty of Medicine, Dept of Histology \& Embryology, Istanbul, Turkey.

EC: $0000-0001-7592-3000$

TI: 0000-0001-8272-4931

YY: 0000-0002-2458-4106

Ethics Committee Approval: There is no need to take an approval due to the design of the paper.

Etik Kurul Onayı: Yazının tipi nedeniyle eitk kurul onamına gerek bulunmamaktadır.

Conflict of Interest: No conflict of interest was declared by the authors.

Çıkar Çatışması: Yazar çıkar çatışması bildirmemiștir.

Financial Disclosure: The authors declared that this study has received no financial support.

Finansal Destek: Yazarlar bu çalışma için finansal destek almadıklarını beyan etmișlerdir.

Geliş Tarihi / Received: 30.01 .2021

Kabul Tarihi / Accepted: 18.03.2021

Yayın Tarihi / Published: 01.04.2021

Sorumlu yazar / Corresponding author

Emel Canbay

Adres/Address: Güzelbahce Str. No: 15 Nisantasi, Istanbul, Turkey.

e-mail: drecanbay@gmail.com

Tel/Phone: +90 2122960909

\section{Copyright $($ ACEM}




\section{Introduction}

Epithelial ovarian carcinoma (EOC) arises from the surface epithelium composed of peritoneal mesothelial cells [1]. Patients with EOC usually present at advanced stages of the disease due to the absence of symptoms in the early stages.

There are four main types of EOC: serous ovarian carcinoma (30\% to $70 \%$ ), mucinous ovarian carcinoma (5\% to $20 \%$ ), endometrioid ovarian carcinoma (10\% to $20 \%$ ), clear cell carcinoma (3\% to $10 \%$ ) as well as a small group of transition cells (Brenner tumor) (1\%) and mixed epithelial carcinosarcoma (3\%) [2]. EOC, fallopian tube carcinoma, and primary peritoneal carcinoma (PPC) are treated as a single disease entity according to NCCN protocol.

The latest evidence showed that the fallopian tube carcinomas might also be the source of some EOC subtypes [3]. EOC usually remains in the peritoneum, a barrier to all peritoneal surfaces in the abdominal cavity. Therefore, EOC is generally designated as a Peritoneal Surface Malignancy (PSM). The surgeons specializing in peritonectomy procedures and hyperthermic intraoperative chemotherapy believe that these patients can be treated or even cured with cytoreductive surgery, including peritonectomy and combinations of intraperitoneal and systemic chemotherapy.

Here, we would like to review the standard care of the EOC and evidence-based treatment success of intraperitoneal chemotherapy applications such as hyperthermic intraperitoneal chemotherapy with an ultraradical surgical approach.

\section{for EOC}

\section{Standard of care as a first-line therapy}

The standard systemic chemotherapy regimen for EOC is the combination of carboplatin (CarboDDP) area under curve 5 or 6 and paclitaxel (PTX) $175 \mathrm{mg} / \mathrm{m} 2$ administered every three weeks [4]. The benefit of secondary surgery in patients who had a residual tumor size bigger than $1 \mathrm{~cm}$ after primary surgery as part of first-line therapy was evaluated in the EORTC-55865 trial [5]. This trial included FIGO stage IIb-IV patients with residual disease to complete $\geq \mathrm{X} 6$ chemotherapy or $3 \mathrm{Xchemotherapy}$ followed by interval debulking surgery (IDS) and then additional adjuvant X3 chemotherapy. There are significant survival advantages in patients who underwent IDS, according to the result of this study. Unfortunately, this result has not been confirmed in the GOG-152 trial. When the chemotherapy regimen is replaced with a combination of paclitaxel (PTX) and cisplatin (CDDP) instead of cyclophosphamide and cisplatin, OS has shown no superiority to each other between IDS and primary DS groups. Accordingly, the IDS approach did not improve OS in these patients [6].

\section{Intraperitoneal chemotherapy}

EOC is confined into the peritoneal cavity as a natural feature of the disease. Therefore, locoregional treatment has been considered as a treatment option of EOC for almost three decades. Indeed, GOG-172 was designed for small volume residual disease [7] (Table 1). A significant increase in progression-free survival (PFS) and 15.9 months OS with intraperitoneal (IP) chemotherapy arm than systemic chemotherapy arm with this trial. Two more large phase III trials GOG 104 [8] and GOG 114 [9], have also demonstrated longer OS compared to systemic chemotherapy $(\mathrm{p}<0.05)$ (Table 1). IP chemotherapy's role in treating newly diagnosed advanced EOC has not been subjected to controversy for almost three decades. Also, IP chemotherapy is not widely used in US or European Centers due to the high rate of complication and low rate of completing six cycles of chemotherapy, even though both NCI accepted, and Phase III trials indicated that the IP treatment has a survival superiority systemic chemotherapy.

In EOC treatment, physicians do not prefer IP chemotherapy due to complications such as catheter-related complications that may develop due to IP chemotherapy. We demonstrated in our unpublished series that i.p. chemotherapy can be tolerated safely and effectively for up to four cycles in patients with peritoneal metastasis. Other experts also reported that i.p. chemotherapy could be well tolerated for up to 6 cycles for peritoneal metastases.

Besides these studies, the GOG-252 trial reported that IP chemotherapy did not have an OS advantage to the systemic chemotherapy when bevacizumab was added to both IP and systemic chemotherapy arms [10]. GOG 252 has another advancement toward identifying upfront treatment of advanced stages EOC using combinations of the systemic use of bevacizumab with IP platinum and paclitaxel.

Altogether, these trials unfortunately failed to define IP chemotherapy's exact role in advanced EOC at the time of initial diagnosis. GOG-104 did not assess progression-free survival with cyclophosphamide. GOG-114 was designed with high dose induction chemotherapy and a weekly and dose intense regimen in the IP arm that seems irrelevant for clinical practice. Finally, GOG 252 is the only trial that evaluated the effect of chemotherapy with IP route and a comparison of cisplatin with carboplatin. More recently, the advantage of IP chemotherapy was analyzed on OS. This study showed that IP chemotherapy has some advantages as OS beyond ten years, effective cytotoxicity in patients with macroscopic (gross) residual disease of $<1 \mathrm{~cm}$; and prolonged OS in association with the number of IP cycles was detected when the retrospective data of GOG 114 and 172 compared [11].

\section{Dose dense therapy}

Novel trial testing dose-dense weekly paclitaxel showed longer progression-free survival (28.1 vs. $17.5 \mathrm{mo})$ and better median OS (100.5 vs. $62.2 \mathrm{mo}$ ) in patients with OC [12]. However, this survival benefit could not be confirmed in the Western GOG-262 Trial (median OS 40.2 vs. 39.0 months) [13]. This trial also supported that bevacizumab alone was effective as much as weekly paclitaxel dose-dense therapy. According to the ICON-8 trial, weekly dose-dense therapy of paclitaxel as a part of first-line therapy did not prolong progression-free survival [14]. Progression-free survival also did not show a difference between carboplatin/paclitaxel regimen and weekly carboplatin plus paclitaxel regimen according to Multicenter Italian Trials [15].

\section{Molecular therapy}

Angiogenesis is the initiation stage of tumorigenesis for tumor proliferation and invasion. Therefore, Anti-angiogenic therapy and, more recently, BRCA mutation have also been selected as a targeted molecular therapy of EOC. Indeed, vascular endothelial growth factor (VEGF) has been reported as the most important progressive factor for EOC [16]. In this study, progression-free survival is significantly longer in the bevacizumab arm, whereas OS was not different in double-blind 3 -arm with bevacizumab and paclitaxel carbo platinum in the GOG-18 study [17]. A similar result with no OS and no 
progression-free survival benefit was also reported using bevacizumab to the standard systemic chemotherapy in 2 arm ICON-7 trial [18]. Besides this, progression-free survival and median OS were more remarkable in high-risk group patients with Grade III or clear cell histology in the group added bevacizumab to the Standard chemotherapy arm [18].
The patients were recently randomized for other antiangiogenic agents, Pazopanib (oral tyrosine kinase inhibitor), after completing debulking surgery and standard first-line chemotherapy in the AGO OVAR-16 trial [19]. Again, progression-free survival was improved in the Pazopanib arm, whereas no difference was observed for OS in this study.

Table 1. Intraperitoneal chemotherapy trials for EOC; n: number of the patients; PTX: paclitaxel; CDDP: Cisplatin; iv: intravenous, ip: intraperitoneal; p value $<0.05$ is statistically significant; OAS: overall survival; PFS: progression free survival; Ns: non significant.

\begin{tabular}{|c|c|c|c|}
\hline Study & Regimen & $\begin{array}{c}\text { OAS advantages (months) } \\
\text { ip } v s \text { iv }\end{array}$ & $\begin{array}{c}\text { PFS advantages (months) } \\
\text { ip } v s \text { iv }\end{array}$ \\
\hline GOG 172 [7] & iv PTX+CDDP $v s$ & 65.6 vs $49.7(p=0.03)$ & $23.8 v s 18.3(p=0.05)$ \\
\hline$(n=175)$ & iv PTX with ip PTX+CDDP & & \\
\hline GOG $104[8]$ & ip CDDP/iv CDDP vs & 49 vs $41(p=0.02)$ & Ns $v s \mathrm{Ns}$ \\
\hline$(n=546)$ & iv CDDP/iv cyclophosphamid & & \\
\hline GOG 114 & High-dose iv carboplatinx ip CDDP vs & 63 vs $52(p=0.05)$ & 28 vs $22(p=0.01)$ \\
\hline$(n=462)$ & iv paclitaxel/iv CDDP & & \\
\hline GOG 252 & ip carboplatin/iv PTX+bevacizumab vs & & $28.7(p=0.41)$ \\
\hline$(\mathrm{n}=1381)$ & ip CDDP/ivPTX/ip PTX day 8 & & $27.8(p=0.73)$ \\
\hline $\begin{array}{l}\text { ICON } 7 \\
(n=1528)\end{array}$ & $\begin{array}{l}\text { iv carboplatin/iv PTX/iv bevacizumab-placebo for } 1 \text { year } v s \\
\text { iv carboplatin+iv PTX/iv bevacizumab by bevacizumab for } 1 \\
\text { year }\end{array}$ & 45.5 vs $44.6(p=0.85)$ & 24.1 vs $22.4(p=0.04)$ \\
\hline
\end{tabular}

Trebananib is a recombinant peptide that blocking the binding of Angiopoietin-1 and -2 to Tie 2 to inhibit angiogenesis. Trinova-3/ENGOT-ov2 Phase III trial did not support additional overall survival improvement compared to systemic carboplatin and paclitaxel treatment [20]

Nintedanib, which is a potent oral inhibitor of growth factor receptors (vascular growth factor receptors-1,-2,-3; platelet-derived growth factor receptors- $\alpha,-\beta$ and fibroblast growth factor

receptors), has been investigated as first-line chemotherapy in addition to standard systemic chemotherapy in AGO-OVAR-12 as Phase III clinical trial [21]. Even though OS has not been reported, progression-free survival was improved with Nintedanib arm in addition to systemic chemotherapy in patients with EOC after primary complete surgical resection.

In addition to these achievements, the inhibitors of the enzyme poly-ADP ribose polymerase (PARP) promise new agents that report impressive survival improvement in recurrent EOC [22]. This result led to the design of the PAOLA, PRIMA, GOG-3005, and SOLO-trials to investigate the role of PARP inhibitors in the first-line maintenance therapy. SOLO-1 Phase III trial was designed in BRCA1/2 mutated EOC patients who primarily responded to platinum-based chemotherapy. These patients were received two years of Olaparib therapy. Progression-free survival was improved by $70 \%$, with a lower risk of disease recurrence. Progression or death was found to be lower in Olaparib's arm.

\section{Neoadjuvant chemotherapy}

Neoadjuvant chemotherapy (NAC) followed by interval debulking surgery and adjuvant chemotherapy has also been considered in stage IIIC and Stage IV patients with EOC to achieve complete resection. NAC was investigated in EORTC trial 55971 [23] and Chorus Trial [24]. However, OS or progression-free survival was not improved with NAC whereas less complication and lower postoperative mortality were recorded in the NAC arm. Therefore, NAC seems to be very important in decreasing morbidity and mortality related to surgery. Two further studies, JCOG-602 [25] and SCORPION trial [26], also reported similar results for NAC, but also NAC did no have inferiority to surgery.

\section{Surgery and HIPEC}

Complete cytoreduction to remove all macroscopic residual disease is the most important independent prognostic factor to prolong overall survival and even to cure patients with EOC [23]. Indeed, when the surgical series were examined, some patients had a bulky residual tumor after surgery.

Therefore, surgery and experience in upper abdominal surgery with peritonectomy procedures seem to be essential to perform surgery to achieve maximum surgical success. Peritoneal Surface Oncology Group International (PSOGI) has been designated as the organization aiming to standardize the techniques and procedures for diseases characterized by peritoneal metastasis. The peritoneum is also considered as a potential metastasis site for EOC. We consider that peritoneum is the potential metastasis site of EOC due to the peritoneal metastasis being a part of this disease's natural history. Therefore, a combination of radical surgical resections with peritonectomy procedures and intracavitary application of heated chemotherapy was developed by peritonectomy surgeons.

The rationale of HIPEC is that locoregional disease could only be treated with the addition of regional therapies to the systemic therapy. Peritonectomy surgeons also perform complete surgical resections with total greater and lesser omentectomy. Then HIPEC is added to kill intraabdominal microscopic tumor cells that penetrated the intraperitoneal tissue after surgical resection. This relatively new therapeutic approach, which consists of the addition of HIPEC to cytoreductive surgery, has been widely used by surgeons dealing with peritoneal metastasis developed from appendiceal mucinous neoplasms and colorectal cancer.

The first report of HIPEC performed for EOC was presented in 1993 [27]. Then, 141 patients with EOC were treated with cytoreductive surgery and HIPEC either frontline, 
interval debulking, for recurrence and consolidation [28]. Platinum sensitive disease, shorter hospital stays and completeness of cytoreduction were found to be associated with increased overall survival, and the median OS was 30.3 months.

A systematic review and meta-analysis demonstrated that the benefit of HIPEC in addition to cytoreductive surgery was up to 8 years compared to cytoreductive surgery alone. Cytoreductive surgery with HIPEC had significantly better 1year survival than standard surgery and systemic chemotherapy group [29].

More recently, there are two phase III trials investigating the effects of HIPEC. The first multicenter randomized study was designed by adding HIPEC to frontline cytoreductive surgery that showed no benefit for both progression-free survival and OS with HIPEC. These results were presented at ASCO Annual Meeting 2017 [30]. However, Van Driel et al. [31] investigated the effects of HIPEC in addition to the interval debulking surgery in patients with stage III EOC patients. The median progression-free survival was 14.2 months in the cytoreductive surgery plus-HIPEC group, whereas it was 10.7 months in the cytoreductive surgery group alone. Median overall survival was 45.7 months in the cytoreductive surgery-plus-HIPEC group and 33.9 months in the cytoreductive surgery group. These results showed a 12 -month improvement in OS with the addition of HIPEC to cytoreductive surgery in interval debulking surgery setting [32].

A phase III prospective randomized study on HIPEC in recurrent cases reported an improved overall survival up to 13.3 months [32]. However, this trial was reported to have limitations such as statistical analysis and randomization, and validity problems [33].

There are several limitations of the above studies. Firstly, all studies were reported by Gynecologic Oncology groups. Peritoneal metastasis of EOC can be considered as a gynecologic oncological disorder. However, Stage IIIC EOC is already metastatic disease and the disease spreads into the peritoneal surface in the entire abdomen. When the PM of OC develops the right diaphragmatic and the left diaphragmatic surface and subcapsular area of the liver with lesser and greater omentum and omental bursa are heavily affected with the disease as much as pelvic peritoneum and bowels and their mesentery. These areas are called as upper abdomen and can be resected by peritonectomy surgeons easily. Therefore, incomplete cytoreduction is highly likely performed during the first surgery due to non-resected greater and lesser omentum and diaphragmatic peritoneum in these cases. These patients are also admitted to gynecologic surgery departments when the ascites or Stage IIIC ovarian carcinoma was occurred. Oncological surgeons might involve the surgery if they were called by the patients or the gynecologic oncologists during surgery. Therefore, above studies were carried out by gynecological oncologists. Based on peritoneal spreading of the disease, PM of OC can be managed with both peritonectomy surgeons and gynecologic oncologists specialized for OC. Therefore, above studies have a limitation to achieve complete cytoreduction to leave no macroscopic disease either in upfront surgery arms or in neoadjuvant arms. Again, a collaborative effort between surgical oncology and gynecological oncology seems to be not possible even though both groups' efforts are the cure of these patients. Secondly, intraperitoneal port placement and intraperitoneal chemotherapy are challenging and invasive procedures.
Therefore, the intraperitoneal chemotherapies perform in special trained centers in worldwide. Intraperitoneal port can cause intraabdominal infection and sepsis and perforation and obstruction and fibrosis. These serious complications prevent the widely use of intraperitoneal chemotherapy and as well as HIPEC in all centers.

In addition to peritonectomy procedures as surgical training, intraperitoneal chemotherapy applications and usage of intraperitoneal chemotherapy need to be optimized and to become standard protocol for these patients. Altogether, we still have failed to cure these patients with these standard treatment protocols stated previously.

In conclusion, the standard of care for peritoneal metastasis of EOC is debulking surgery and followed by a combination of paclitaxel and carboplatin as a frontline therapy. The addition of bevacizumab to standard chemotherapy is suggested for patients with a high risk of disease progression. To date, the effects of HIPEC were not determined except the last Phase III trial supporting the improvement in overall survival with HIPEC in primary cases of EOC.

To achieve the cure of this disease;

- Subgroups of EOC need to be classified on molecular bases and documented well with symptoms and pathological characteristics.

-Neoadjuvant chemotherapy approach needs to be improved by changing the route of application such as intracavitary applications of chemotherapy.

-The role of hyperthermia and pressurized application of intraperitoneal chemotherapy applications need to be well characterized with future studies.

Intraoperative diagnosis of peritoneal metastasis needs to be improved.

- Multicenter randomized clinical trials with specialized surgeons and gynecological oncologists and medical oncologists and pathologists seem essential.

Consensus statements need to be developed with the shared efforts of gynecological oncologists and surgeons and medical oncologists, and pathologists.

The clinical significance of HIPEC and other techniques needs to be clarified, and the standard of care effort for the selection of the patients needs to be defined with international collaborative effort.

Therefore, new treatment strategies seem to be essential to cure these patients from their initial treatment stages.

\section{References}

1. van Niekerk CC, Vooijs P, Casparie-van Velsen IJ, Poels LG. Differentiation margins of ovarian tumor pathology: first incidences of epithelial ovarian tumors monitored by marker antibodies. Cancer Detect Prev. 1997;21:247-57.

2. Diagnosis:Types of Tumors.2019,

http://ovariancancer.jhmi.edu/malignantepithelial.cfm.

3. Piek JM, van Diest PJ, Verheijen RH. Ovarian carcinogenesis: an alternative hypothesis. Adv Exp Med Biol. 2008;622:79-87.

4. Is R, Parmar M, Pecorelli S, Pfisterer J, Poveda A, Provencher D, et al. 2004 consensus statements on the management of ovarian cancer: final document of the 3rd International Gynecologic Cancer Intergroup Ovarian Cancer Consensus Conference (GCIG OCCC 2004). Ann Oncol. 2005;16 Suppl 8:viii7-viii12. 
5. van der Burg ME, van Lent M, Buyse M, Kobierska A, Colombo N, Favalli G, et al. The effect of debulking surgery after induction chemotherapy on the prognosis in advanced epithelial ovarian cancer. N Engl J Med. 1995;332:629-34.

6. Rose PG, Nerenstone S, Brady MF, Clarke-Pearson D, Olt G, Rubin SC, et al; Gynecologic Oncology Group. Secondary surgical cytoreduction for advanced ovarian carcinoma. N Engl J Med. 2004;351:2489-97.

7. Armstrong DK, Bundy B, Wenzel L, Huang HQ, Baergen R, Lele $\mathrm{S}$, et al; Gynecologic Oncology Group. Intraperitoneal cisplatin and paclitaxel in ovarian cancer. N Engl J Med. 2006;354:34-43.

8. Alberts DS, Liu PY, Hannigan EV, O'Toole R, Williams SD, Young JA, et al. Intraperitoneal cisplatin plus intravenous cyclophosphamide versus intravenous cisplatin plus intravenous cyclophosphamide for stage III ovarian cancer. N Engl J Med. 1996;335:1950-5.

9. Markman M, Bundy BN, Alberts DS, Fowler JM, ClarkPearson DL, Carson LF, et al. Phase III trial of standard-dose intravenous cisplatin plus paclitaxel versus moderately high-dose carboplatin followed by intravenous paclitaxel and intraperitoneal cisplatin in small-volume stage III ovarian carcinoma: an intergroup study of the Gynecologic Oncology Group,

Southwestern Oncology Group, and Eastern Cooperative Oncology Group. J Clin Oncol. 2001;19:1001-7.

10. Walker JL, Brady MF, Wenzel L, Fleming GF, Huang HQ, DiSilvestro PA,et al. Randomized Trial of Intravenous Versus Intraperitoneal Chemotherapy Plus Bevacizumab in Advanced Ovarian Carcinoma: An NRG Oncology/Gynecologic Oncology Group Study. J Clin Oncol. 2019;37:1380-90.

11. Tewari D, Java JJ, Salani R, Armstrong DK, Markman M, Herzog T, Monk BJ, Chan JK. Long-term survival advantage and prognostic factors associated with intraperitoneal chemotherapy treatment in advanced ovarian cancer: a gynecologic oncology group study. J Clin Oncol. 2015;33:1460-6.

12. Katsumata N, Yasuda M, Isonishi S, Takahashi F, Michimae H, Kimura E, et al; Japanese Gynecologic Oncology Group. Longterm results of dose-dense paclitaxel and carboplatin versus conventional paclitaxel and carboplatin for treatment of advanced epithelial ovarian, fallopian tube, or primary peritoneal cancer (JGOG 3016): a randomised, controlled, open-label trial. Lancet Oncol. 2013;14:1020-6.

13. Chan JK, Brady MF, Penson RT, Huang H, Birrer MJ, Walker JL, et al.. Weekly vs. Every-3-Week Paclitaxel and Carboplatin for Ovarian Cancer. N Engl J Med. 2016;374:738-48. 14. Clamp AR, James EC, McNeish IA, Dean A, Kim JW, O'Donnell DMet al. Weekly dose-dense chemotherapy in first-line epithelial ovarian, fallopian tube, or primary peritoneal carcinoma treatment (ICON8): primary progression free survival analysis results from a GCIG phase 3 randomised controlled trial. Lancet. 2019;394:2084-95.

15. Pignata S, Scambia G, Katsaros D, Gallo C, Pujade-Lauraine E, De Placido S, et al. Carboplatin plus paclitaxel once a week versus every 3 weeks in patients with advanced ovarian cancer (MITO-7): a randomised, multicentre, open-label, phase 3 trial. Lancet Oncol. 2014;15:396-405.

16. Belotti D, Calcagno C, Garofalo A, Caronia D, Riccardi E, Giavazzi R, et al. Vascular endothelial growth factor stimulates organ-specific host matrix metalloproteinase- 9 expression and ovarian cancer invasion. Mol Cancer Res. 2008;6:525-34.

17. Tewari KS, Burger RA, Enserro D, Norquist BM, Swisher EM, Brady MF, et al. Final Overall Survival of a Randomized Trial of Bevacizumab for Primary Treatment of Ovarian Cancer. J Clin Oncol. 2019;37:2317-28.

18. Perren TJ, Swart AM, Pfisterer J, Ledermann JA, PujadeLauraine E, Kristensen Get al; ICON7 Investigators. A phase 3 trial of bevacizumab in ovarian cancer. N Engl J Med. 2011;365:248496.

19. Vergote I, Hanker LC, Floquet A, Rau J, Kim JW, Ortega E, et al. AGO-OVAR 16: a phase III study to evaluate the efficacy and safety of pazopanib (PZ) monotherapy versus placebo in women who have not progressed after first line chemotherapy for epithelial ovarian, fallopian tube, or primary peritoneal canceroverall survival (OS) results J. Clin. Oncol. 2018;36:5518-5518. 20. Vergote I, Scambia G, O'Malley DM, Van Calster B, Park SY, Del Campo JM, et al. Trebananib or placebo plus carboplatin and paclitaxel as first-line treatment for advanced ovarian cancer (TRINOVA-3/ENGOT-ov2/GOG-3001): a randomised, doubleblind, phase 3 trial. Lancet Oncol. 2019;20:862-76.

21. du Bois A, Kristensen G, Ray-Coquard I, Reuss A, Pignata S, Colombo N, et al. Standard first-line chemotherapy with or without nintedanib for advanced ovarian cancer (AGO-OVAR 12): a randomised, double-blind, placebo-controlled phase 3 trial. Lancet Oncol. 2016;17:78-89.

22. Mirza MR, Monk BJ, Herrstedt J, Oza AM, Mahner S, Redondo A, et al. Niraparib Maintenance Therapy in PlatinumSensitive, Recurrent Ovarian Cancer. N Engl J Med. 2016;375:2154-64.

23. Vergote I, Amant F, Kristensen G, Ehlen T, Reed NS, Casado A. Primary surgery or neoadjuvant chemotherapy followed by interval debulking surgery in advanced ovarian cancer. Eur J Cancer. 2011;47 Suppl 3:S88-92.

24. Kehoe S, Hook J, Nankivell M, Jayson GC, Kitchener H, Lopes T, et al. Primary chemotherapy versus primary surgery for newly diagnosed advanced ovarian cancer (CHORUS): an openlabel, randomised, controlled, non-inferiority trial. Lancet. 2015;386:249-57

25. Onda T, Satoh T, Ogawa G, Saito T, Kasamatsu T, Nakanishi $\mathrm{T}$, et al; Japan Clinical Oncology Group. Comparison of survival between primary debulking surgery and neoadjuvant chemotherapy for stage III/IV ovarian, tubal and peritoneal cancers in phase III randomised trial. Eur J Cancer. 2020;130:114-25.

26. Fagotti A, Ferrandina MG, Vizzielli G, Pasciuto T, Fanfani F, Gallotta V, et al. Randomized trial of primary debulking surgery versus neoadjuvant chemotherapy for advanced epithelial ovarian cancer (SCORPION-NCT01461850). Int J Gynecol Cancer. 2020;30:1657-64.

27. McQuellon RP, Loggie BW, Lehman AB, Russell GB, Fleming RA, Shen $P$, et al. Long-term survivorship and quality of life after cytoreductive surgery plus intraperitoneal hyperthermic chemotherapy for peritoneal carcinomatosis. Ann. Surg. Oncol. 2003;10:155-62.

28. Helm CW, Richard SD, Pan J, Bartlett D, Goodman MD, Hoefer R, et al. Hyperthermic intraperitoneal chemotherapy in ovarian cancer: first report of the HYPER-O registry. Int J Gynecol Cancer. 2010;20:61-9.

29. Huo YR, Richards A, Liauw W, Morris DL. Hyperthermic intraperitoneal chemotherapy (HIPEC) and cytoreductive surgery (CRS) in ovarian cancer: A systematic review and meta-analysis. Eur J Surg Oncol. 2015;41:1578-89.

30. Lim MC, Chang SJ, Yoo HJ, Nam BH, Bristow R, Park SY, et al. Randomized trial of HIPEC in women with primary advanced peritoneal ovarian and tubal cancer J Clin Oncol. 2017;35:5520. 31. van Driel WJ, Koole SN, Sonke GS. Hyperthermic Intraperitoneal Chemotherapy in Ovarian Cancer. N Engl J Med. 2018;378:1363-4.

32. Spiliotis J, Halkia E, Lianos E, Kalantzi N, Grivas A, Efstathiou E, et al. Cytoreductive surgery and HIPEC in recurrent epithelial ovarian cancer: a prospective randomized phase III study. Ann Surg Oncol. 2015;22:1570-5.

33. Harter P, Reuss A, Sehouli J, Chiva L, du Bois A. Brief Report About the Role of Hyperthermic Intraperitoneal Chemotherapy in a Prospective Randomized Phase 3 Study in Recurrent Ovarian Cancer From Spiliotis et al. Int J Gynecol Cancer. 2017;27:246-7. 